TRIGGERING FACTORS FOR DRUG ABUSE IN WOMEN ${ }^{1}$

\author{
Sônia Regina Marangoni², Magda Lúcia Félix de Oliveira
}

${ }^{1}$ Partial result of the dissertation - Contexts of social exclusion and vulnerability of pregnant women in pregnancy puerperal cycle, submitted to the Nursing Graduate Program (PSE) of the State University of Maringá (UEM), in 2011.

${ }^{2}$ Master in Nursing. RN, Regional University Hospital of Maringá. Maringá, Paraná, Brazil. E-mail: sonia.marangoni@yahoo. com.br

${ }^{3}$ Ph.D. in Collective Health. Professor of the Nursing Department and the PSE/UEM. Maringá, Paraná, Brazil. E-mail: mlfoliveira@uem.br

ABSTRACT: The purpose of this study was to identify and discuss the triggering factors for drug abuse in women. This descriptive qualitative study was developed with 12 women from three municipalities in the state of Paraná, referred to a toxicological care center, between 2008 and 2010. Data were collected from the toxicological occurrence forms of the medical records, and from the script of the semi-structured interviews applied during home visits, and submitted to thematic content analysis. Most women had pardo race/ skin color, were aged between 17 and 33 years, and lived in common-law marriage. The triggering factors for drug abuse were related with the individual characteristics of the women and sociocultural factors. The factors that stood out were younger groups, low level of education, low participation in the labor market, family conflicts, and drug dealing and use by spouses and relatives. A weak emotional bond was identified, with inadequate family dynamics. Friends, relatives, and spouses have favored the addictive behavior. DESCRIPTORS: Causality. Addictive behavior. Illicit drugs. Substance-related disorders. Women's health.

\title{
FATORES DESENCADEANTES DO USO DE DROGAS DE ABUSO EM MULHERES
}

RESUMO: O objetivo deste estudo foi identificar e discutir fatores desencadeantes do uso de drogas em mulheres. Estudo qualitativo de caráter descritivo com 12 mulheres provenientes de três municípios do Paraná, notificadas a um centro de assistência toxicológica nos anos 2008 a 2010. Os dados foram coletados da ficha de Ocorrência Toxicológica dos prontuários, e do roteiro para entrevista semiestruturado aplicado durante visita domiciliar e analisados por conteúdo temático. A maioria era da raça/cor parda, estava entre 17 e 33 anos e convivia em união estável. Os fatores desencadeantes do uso de drogas estavam relacionados às características individuais das mulheres e aspectos socioculturais. Destacaram-se a faixa etária precoce, baixa escolaridade, baixa inserção no mercado de trabalho, conflitos intrafamiliares e o uso e tráfico de drogas pelos companheiros e parentes. Verificaram-se vínculo afetivo fraco, com dinâmica familiar inadequada. Amigos, familiares e companheiros favoreceram o comportamento aditivo.

DESCRITORES: Causalidade. Comportamento aditivo. Drogas ilícitas. Transtornos relacionados ao uso de substâncias. Saúde da mulher.

\section{FACTORES DESENCADENANTES DEL USO DE DROGAS EN MUJERES}

RESUMEN: El objetivo fue identificar y discutir factores desencadenantes del uso de drogas en mujeres. Estudio cualitativo de carácter descriptivo con 12 mujeres provenientes de tres municipios de Paraná, notificadas a un centro de asistencia toxicológica en los años 2008 a 2010. Los datos fueron colectados de la ficha de Incidencia Toxicológica, de los expedientes, y del itinerario para entrevista semiestructurado aplicada durante visita domiciliar y analizados por contenido temático. La mayoría era de la raza/color pardo, estaba entre 17 y 33 años y convivía en unión estable. Los factores desencadenantes del uso de drogas estaban relacionados a las características individuales de las mujeres y aspectos socio-culturales. Se destacaron la edad precoz, baja escolaridad, baja inserción en el mercado de laboral, conflictos intrafamiliares y el uso y tráfico de drogas por los compañeros y familiares. Se verificaron vínculo afectivo débil, con dinámica familiar inadecuada. Amigos, familiares y compañeros favorecieron el comportamiento adictivo.

DESCRIPTORES: Causalidad. Comportamiento adictivo. Drogas ilícitas. Trastornos relacionados con sustancias. Salud de la mujer. 


\section{INTRODUCTION}

Drug use is a millennial and universal human practice. In several ancient societies, drugs were used with religious, cultural and medicinal purposes. However, as of the $20^{\text {th }}$ century, this consumption became a worldwide concern because of its high frequency and the social damages related with drug use and illegal dealing. Few social phenomena have a higher cost than drug abuse in terms of law and health, family difficulties and news in the worldwide media. ${ }^{1-2}$ The difference between drug use in past and present, though, is that they are no longer an element of integration, a cohesion factor at social and emotional levels, as seen in ancient societies. Currently, the consumption of drugs occurs in an individualized and abusive manner, due to the huge quantity of substances available in the market and to their easy purchase; elements that contribute to the dissemination and initiation in consumption. ${ }^{1-2}$

In general, abuse drugs are classified, as for the legal status of their substances, as licit or illicit. Licit drugs have federal permission to be produced, and its trading and use are not criminalized, being represented mainly by alcohol, tobacco and medications, whereas illicit drugs cannot be traded, thus production and dealing of these substances are subject to criminalization and repression. The most frequently used drugs are marijuana, powder or alkalinized cocaine, and heroin. Drugs are also classified according to their action mechanism or the effect they cause on the central nervous system as depressants, stimulants or hallucinogens. ${ }^{3}$

Historically, problems related with the consumption of alcohol and other drugs were more common among men, but changes in the women's social role have determined the decrease of this difference. Currently, it is observed that drug dependence affects subgroups with heterogeneous characteristics. ${ }^{4}$ Other aspects related to increased consumption in the female population are the stimuli given to licit drugs such as alcohol, tobacco and anorectic drugs by the media, which tends to associate drug use with beauty, seduction, professional success and wealth. In addition, this psychological appeal of the media also influences adolescents negatively. ${ }^{1,5}$

Another relevant factor is that, in many cases, the use of tobacco and alcohol starts prema- turely in the family environment or among friends. Social representations that lead to drug use or disapproval depend on the woman's sociocultural and family context, since the meanings attributed to the use of these substances differ across social groups, including in families. ${ }^{2,6-7}$

Consequently, it is verified that the morbimortality associated with the use of alcohol is emphasized among women, who present higher rates of liver cirrhosis than men; also, hormone actions probably contribute significantly to the liver damage caused by alcohol. Moreover, arterial hypertension, anemia, malnutrition, gastrointestinal ulcers, heart diseases, and psychiatric disorders advance faster in women. There are hypotheses that drugs such as cocaine, marijuana, and tranquilizing and stimulant agents have more harmful effects in women. Still, most of the studies developed to establish clinical evidence focus on men. ${ }^{4}$

Over the last few years, a growing number of female users of alcohol and other abuse drugs have been admitted in public hospitals, with clinical, surgical and obstetric complications due to their addictive behavior. Due to legal restrictions existing in Brazil, the dependence situation is only known by the health team during hospitalization, which occurs mainly in the event of withdrawal crises or typical attitudes characterizing drug use, such as craving and weight loss.

Considering that the drug abuse phenomenon among women has been influenced by economical, social, and cultural processes of different societies, learning the triggering factors for drug abuse in women, who are "hidden" from society, contributes to guide health actions aimed at mother and child, mainly in terms of public policies that protect and address this particular subgroup of the population. ${ }^{8}$

Triggering factors for drug use take place before the inappropriate use and are associated, statistically, with an increased probability of initiation and maintenance of drug abuse. These factors are related with different social contexts, such as the family, peers, school, community and media. ${ }^{9}$

On the other hand, a change has been described in the behavior of drug users at certain turning points, in which significant life events tend to favor the interruption of consumption, leading individuals to change from a compulsive behavior regarding drug use to controlled patterns, as a self- 
regulation measure of the user. ${ }^{10}$ The experience of pregnancy and maternity should constitute a turning point, with consequent drug use decrease or withdrawal.

In this context, the present study aimed to identify and discuss triggering factors for drug abuse among women.

\section{MATERIAL AND METHODS}

This qualitative descriptive study was developed based on retrospective data from a series of cases involving female abuse drug users, who were hospitalized during pregnancy.

Study participants were 12 women with medical or nursing records indicating acute or chronic drug intoxication during pregnancy. Pregnant women were chosen as study subjects given the understanding that pregnancy should work as a turning point. These women lived in three municipalities in the northwest region of the state of Paraná - Maringá, Sarandi and Paiçandu, and were referred to a Toxicological Control and Care Center (TCCC) in northwest Paraná, between 2008 and 2010. Data were collected from epidemiological forms of toxicological occurrence (TO) of the TCCC, hospital records, and a semi-structured interview script, which was applied between May and July of 2011.

The TO form - a national standard instrument used to register all intoxication cases - provided data regarding the identification of the patient, the toxicological occurrence, the treatment performed, the clinical evolution and the case outcome. Hospital records provided information regarding the clinical-obstetric complications that triggered hospitalization and the treatment received.

The semi-structured interview script consisted of four thematic axes - characteristics of the woman, characteristics of the family, social and health indicators of the family and hospitalization data. Only part of this script was used in the present study, emphasizing the sociodemographic data of the women and the sociocultural factors associated with the family - drugs used, addictive behavior, diagnosed comorbidities, conflict situations within the family and with the law.

Interviews were performed during home visits, a single meeting with each participant, which lasted 60 minutes in average. During the interviews, the women reported relevant events and facts in their lives that favored drug abuse. All participants signed the Free and Informed Consent Form, and authorized the interviews to be digitally recorded and disposed after full transcription of their contents.

Subjects were identified as per their initials, and their statements were analyzed by means of content analysis, ${ }^{11}$ and grouped in two thematic categories: triggering factors for drug abuse and vulnerability situations experienced over life.

The research proposal was submitted to the Human Research Ethics Committee of the State University of Maringá, and approved under the protocol n. 065/2011.

\section{RESULTS AND DISCUSSION}

\section{Characteristics of the women and drug use}

The age of the participants varied between 17 and 33 years, mean of 25.7 years. Seven women stated their race/skin color was pardo, five were single and seven lived with a partner in common-law marriage. None of the women had an educational level compatible to their age, and most of them were four years behind the expected educational level.

The analysis of the occupational status indicated that none of the interviewees were formally employed at the time of interview - ten women stated they were housewives and two were homeless. Nine women did not have a fixed income and survived with their children's alimony or with the governmental family aid program.

The main reasons for hospitalization were childbirth and injuries resulting from violence. During the period of hospitalization, they informed the medical or nursing team regarding the addictive behavior, or presented signs and symptoms compatible with drug withdrawal syndrome, being diagnosed with chronic drug intoxication.

All participants started using drugs during adolescence, between 12 and 18 years of age; most of them started before they were 15 years old. Four women reported they started using multiple drugs at 12 years of age (Table 1 ).

Regarding the drug abuse pattern, tobacco was, individually, the first drug used by all women. Tobacco and alcohol were initiation drugs in eight cases, concomitantly, during adolescence. 
Table 1 - Distribution of the abuse drug users in pregnancy, according to the drug use pattern. Maringá-PR, 2011

\begin{tabular}{llrc}
\hline Variables & Description & $\mathbf{n}$ & \% \\
\hline \multirow{2}{*}{ Use initiation (years of age) } & 12 to 15 & 9 & 75.0 \\
& 16 to 18 & 3 & 25.0 \\
Licit drugs in life* & Tobacco & 12 & 100 \\
& Alcohol & 9 & 75.0 \\
& Marijuana & 10 & 83.3 \\
& Crack & 10 & 83.3 \\
& Powder cocaine & 3 & 25.0 \\
Comorbidities & Associated (psychiatric/clinical) & 6 & 50.0 \\
& Psychiatric & 5 & 41.7 \\
& Clinical & 1 & 8.3 \\
\hline
\end{tabular}

* More than one answer was given.

Regarding illicit drugs, marijuana was the first drug used. If on the one hand the woman did not engage in the use of alcohol, on the other hand it appeared as the second drug of choice by four of them, and ten used it throughout life. Powder cocaine was used by three women, who, in the continuation, smoked crack.

Ten women reported the use of crack during their whole pregnancy, indicating that the pregnancy did not work as a turning point for this specific population. In this study, most of the women maintained the use of drugs, harming maternity.

In addition, the women presented a strong addictive behavior as for the drugs used over their lives: tobacco was used by all of them; crack and marijuana were used by ten women; alcohol was used by nine; and powder cocaine by three.

Regarding clinical and psychiatric comorbidities, all 12 women reported health problems related with the use of drugs, individually and/ or in association. Although none of the women in the sample complied with psychiatric treatment, 11 of them presented signs and symptoms of mild mental disorders over their lives, and seven mentioned the treatment of clinical problems which they believed to be related with the use of drugs.

The main psychiatric comorbidities were mood swing (seven), anxiety (three), and signs of withdrawal syndrome and depressive symptoms. Regarding clinical comorbidities: respiratory issues (four) and sexually transmissible diseases (three). Eight interviewees reported unprotected sexual practice, and three stated they occasionally use condoms.

\section{Triggering factors for drug abuse}

In the present study, the triggering factors considered for drug abuse were: gender, age, low education, unemployment, as well as the presence of drugs in the community and the influence of friends, biological relatives and partners (current or former) ${ }^{1,2,4-9}$

Changes in women's social paradigm and the greater availability of abuse drugs in society caused consequences such as the decrease in the ratio between genders, specifically among younger subjects. Female drug users constitute a differentiated group, with their own needs and characteristics, both in terms of diagnosis and treatment and prevention strategies. ${ }^{4,12}$

In the series of cases studied, most of the women already used multiple drugs when they were under 15 years of age; some since childhood. Drug use usually starts in adolescence, a stage of the vital cycle that is marked with deep physical and psychic changes, which make adolescents more vulnerable to violence, sexually transmissible diseases and rites of passage for drug initiation. ${ }^{7,13-14}$

Crack was the most frequently used illicit drug during pregnancy, mentioned by ten women, although three of them reported the use of multiple drugs during pregnancy. According to its psychopharmacological specificities, the prevalent pattern of crack use is described as the binge type, that is, the user tends to use it excessively for hours or even days, continuously, alternating days without using it. ${ }^{10}$ Most of the women, despite being pregnant, presented a 
compulsive drug consumption pattern, specially regarding crack.

It is known that drug use is established based on the dynamics of the relationships between subject, drug and life context, and it is considered that the phenomenon is related to the experiences lived in the family structure and in social and interpersonal relationships. ${ }^{5,7,9}$

The main aspect to face is not the drug itself, but the relationship the individuals establish with it, which influences and is strongly influenced by the universe of interactions, in a heterogeneous phenomenon that is often hard to comprise, involving the subject's private life and personal choices. ${ }^{9}$

The group of women analyzed in this study is similar to previous groups described in the literature in terms of drug users: young adults, in economically active and reproductive phase, unemployed, with low buying power, and incompatible level of education as to their age, conforming the vicious cycle of year repetition and school evasion. ${ }^{14-15}$

Nevertheless, there is the indication of a personal choice: they "denied" maternity in favor of keeping using drugs. They established an exclusive relationship with the drug, either because they chose to or due to the lack of access to health and social support services, in a singular moment, culturally intermediated by donation and abnegation values.

The main reason claimed for the initiation in drug use was the presence of licit or illicit drugs in the community. Drug use initiation is multifactorial and its triggering is not only associated with experimentation, but also with the individuals' need to keep their conscious altered, in a process in which adverse social, individual and family factors are combined so as to increase the probability of dysfunctional continuity of the use. ${ }^{7}$

The women reported being influenced by one or more people in their daily circle of friends, partners and families. They emphasized the influence of friends, who they met in the streets, far from the family environment, in eight cases, and two in the school environment.

I left home to go to school, but I ditched classes to go to the riverside with friends, and we smoked and drank there [...] then I started using marijuana and crack [...] I met a guy at the bar [current partner]. He used marijuana, crack, drank and smoked [...] [then] [...] I started using drugs again [...] I got pregnant [lost custody of her daughter]. My mother threw me out [...] I started living on the streets [...] (FPSX - use of multiple drugs at 14 years of age).
I started using tobacco and alcohol [...] [influenced], by friends, on the streets [...]. Then I started using crack [...] my brother is also a user [...]. [Partner] He is an alcoholic and uses crack [...] (LMN - use of licit drugs at 14 and illicit drugs at 15 years of age).

The social representation regarding the influence of friends, who are also users, triggering drug use initiation among adolescents, reported by most of the study participants, agrees with the literature by pointing out that an adolescent, whose best friends demonstrate tolerance, approval or use drugs, will be more easily led to try it than an individual whose friends avoid and disapprove drug use. ${ }^{9-10}$ Hence, it is observed that the women started using drugs during adolescence, when they were more vulnerable to external influences, and this occurred, mainly, in situations that are distant from standard models for an adult, that is, on the streets.

In addition, the initiation and maintenance of drug use may happen due to the lack of empowerment and social policies. The school excluded, when it should have played its role in education, since evasion or decline in school performance are the first consequences of drug use. In other words, there are flaws in educational policies, and even though it is the obligation of the school to embrace these adolescents, there is not enough physical and personal structure for this function. Prevention must be encouraged in schools, since adolescents ideally attend this place. However, this does not happen. ${ }^{2,9}$

Friends in their daily circle, from the streets or the school environment, were indicated as the main inducers in the search for new experiences, including drug use. Nevertheless, the over-appreciation of the influence of friends, of "bad companies", may result from certain unaccountability or denial of intrafamily issues. ${ }^{2,9}$

It was verified that partners from single or multiple unions exerted a significant influence over the life of eight women, who claimed their love relationships influenced them to using illicit drugs. They had children in these relationships, and four women still kept a conjugal relationship.

I started living with an older man, [he] used and dealt drugs, so I started using marijuana, cocaine and crack [because of this relationship] [...]. My mother and my three brothers also got involved with drug use and dealing [...]. I have been arrested five times; every time I was pregnant [...] [released from prison for a week] (SP - use of multiple drugs at 14 years of age).

I started smoking, influenced by friends, because I thought it was cool. Then, I started drinking [...] I was 
shy, and thought I was ugly [...]. [The drugs] made me feel more relaxed [...], I started using marijuana, cocaine and crack, then I met a guy [...] [partner] he was a user and a dealer [...] [with whom] I traded sex for drugs [...] (AAG - use of licit drugs at 17 and illicit drugs at 20 years of age).

Regarding the role of the family members in the initial approach to the use of drugs, the women mentioned their parents in five circumstances, siblings in three and cousins in one. However, when questioned regarding the presence of family members who used licit or illicit drugs, all participants stated there was a strong addictive behavior in the families, characterized by the presence of multiple drugs, mainly alcohol, tobacco and crack.

My parents and my brother used injectable drugs [...] and died from aids [...] [used multiple drugs]. She [mother] was sick, and asked me to buy her drugs [...]. They [siblings and cousins] were crack users. [...] there were lots of conflicts, fights, gunshots [...] because of the drugs [...] [Cousin] is paraplegic [...] (SCT - use of multiple drugs at 12 years of age).

Regarding illicit drugs, marijuana was mentioned by six women, and powder cocaine by four; however, crack was the most frequent drug, present in ten families.

[Currently] I live on the streets, I live in an abandoned construction site [...] [had five children] none of them lives with me [...] [Three of them live with family members], I don't know about the other two, I gave them away [to strangers] [...]. I use marijuana and crack every day, and I have sex for money [...] (SCT).

In the family context of the 12 interviewed women there were, besides the addictive behavior, permissive and encouraging attitudes towards the consumption of drugs by family members, in the figure of parents, siblings, uncles and aunts, cousins and partners.

I smoked and drank. My father, siblings, cousins and friends did too [...] [living in the state of São Paulo]. Then, I started using marijuana and crack. [...] everyone uses and deals it there [...] (TRM - use of licit drugs at 12 and illicit drugs at 15 years of age).

My siblings smoked. My father used to drink and get aggressive, he was murdered in Paraguay [...]. I have been arrested several times [...] I had one or two rocks [...] I lost custody of my son [...] Last time, I was pregnant [...] (MTS - use of licit drugs at 12 and illicit drugs at16 years of age).

Although the children of parents who use drugs have a greater risk of becoming users, since their behavior serves as a model, a permissive at- titude is more significant in this equation. The family has a decisive role in the creation of conditions related both with the abuse and factors of protection, and during the approach of this phenomenon, it must be considered comprehensively. ${ }^{9}$

The presence of drugs in the family environment favored conflicting interpersonal relationships. Although the interviewees did not identify the family conflict as a triggering factor for drug abuse, 11 of them experienced several conflicting circumstances over their family lives, especially regarding physical and psychological violence.

Eight interviewees stated there were conflicts between their parents, and five of them experienced these violence situations since childhood. As for the frequency of the conflicts, only two women said the conflicts were infrequent.

Six women had suffered sexual violence, two of them within the family. In one of the cases it happened in childhood, when she was abused at ten, by her stepfather; the other, during adolescence, and even though the assailant was not part of the family, he lived with them. She was burned with cigarettes and suffered physical assaults, followed by sexual abuse. The others suffered sexual abuse in the streets, generally, under the effect of drugs.

[The parents] are separated, because there were lots of conflicts, ever since I was a little girl [...] they drank. My friends and I would go out with guys on the streets [...] (TRM).

[The father] always drank [...] my mother left when I was eight months old, so I lived with my grandmother [...]. I think she [mother] used drugs [...], she died with HIV [...]. I used to go out and have sex for money to buy drugs [...] I had to be treated for HPV [...] (AAG).

There were drugs available at home. [Conflicts] when my brother went into withdrawal [...]. [Suffered sexual violence] a guy, who lived with us, burned me with cigarette ends, then he hit and raped me [...] (SP).

Sexual violence is a universal phenomenon that strikes, indistinctively, all social classes, races, religions and cultures, and its true incidence is still unknown. This type of violence is believed to be one of the most underreported and underregistered conditions in the whole world. Most of the records indicate a prevalence of this crime among children and adolescents, which may result in a greater risk for prostitution in adulthood and pregnancy in adolescence. ${ }^{16}$

Moreover, the incidence of verbal, physical and sexual abuse at home is considered a trig- 
gering factor for using drugs. Domestic violence and conflicting situations in the family scope are frequent experiences in the daily living of families with drug addiction history. ${ }^{17}$ In most cases in which violence was practiced in the house of the interviewees, the assailant had drank. Among the seven women who lived in common-law marriage, five reported domestic violence practiced by partners, who were also users of licit and illicit drugs.

He smokes, and when he drinks, he gets aggressive [partner] He is jealous and he has hit me many times [...], I lost a baby [...]. [The father] is alcoholic and aggressive. If he has money, he drinks all day long [...]. We are always fighting at home [...] (RJO - use of licit drugs at 18 years of age).

In this context, the family may be a factor of risk or protection for the use of psychoactive substances. The conflict between parents is one of the most relevant risk factors, since it exposes children and adolescents to hostility, destructive criticism and anger., ${ }^{9,14}$ The family is one of the most important factors influencing the configuration of a favorable environment for the adoption of behaviors, such as the consumption of drugs.

\section{Situations of vulnerability experienced over life}

Regarding the situations of vulnerability experienced by women over life, it was possible to identify: the drug use pattern, family conflicts, love relationships, homeless condition, conflicts with the law (drug dealing and other offenses) and the practice of prostitution. Despite the existence of local governmental social, educational and health programs, they are not capable of meeting the demand generated by this phenomenon.

Nevertheless, the persistence in the use of drugs, despite the individual and social risks to which users are exposed, is articulated with economical questions and macrostructural policies. Studying drug use does not involve dealing with a homogeneous category, but a diversity of lifestyles and social representations., ${ }^{9,14}$ Drugs only contribute with or facilitate dependence. It is necessary to analyze the conditions favoring the use, the needs suppressed by consumption and the factors motivating this consumption. ${ }^{4}$ In the present study, nine women stated they became homeless as adolescents, after they abandoned their families.

I suffered sexual abuse [...] [by the stepfather, at 10 years of age]. My cousins used crack [...]. I started using [multiple drugs] with my first husband. [In the same house] we were in three people [...], I went out with the men [...], sold [house belongings], [...] I stole from people on the streets to use drugs [...] (RAC - use of multiple drugs at 13 years of age).

Living in a homeless situation had a strong meaning in the women's statements, always relating the experience of exclusion with the family problems and the family itself. Regardless the quality of the relationships, family support would be one of the main external resources of the women for the development of coping strategies, while they struggle against the disease, since drug consumption was originated during the phase of greater conflict and need for relationships in a subject's life - adolescence.

My parents fought [alcoholics], I left home when I was 16, I had nowhere to go, I stayed on the streets [...] [that was when] I started using marijuana, influenced by friends [...] I felt ugly and sad (REO - use of licit drugs at 14 and illicit drugs at 17 years of age).

I lived on the streets [...] [I took shelter], in an abandoned clinic. I had sex for money [...], I met a guy [...] [partner], who smoked and used crack. Then I started using [...] I got pregnant [...]. [Son] I gave him away four days after birth. [Practiced] small thefts and sold drugs, so that I could consume [...]. We have been arrested (RCSP - use of licit drugs at 16 and illicit drugs at 17 years of age).

The involvement with drug dealing and with dealers favored the exchange of sex for drugs in nine cases. "Prostitution" was practiced mainly as a way to ensure the frequent use of drugs and/or to earn money to keep it.

Partners represented a strong link for the initial approach and maintenance of the pattern of exclusivity with the drug, evolving to the involvement with drug dealing and conflicts with the law. Eight women had already been engaged in drug dealing, and seven had committed other crimes on the streets and in the family environment. In addition, five women reported being arrested due to the involvement with drug dealing, in several circumstances.

My first husband and my brother were drug users and dealers [...] [influenced] marijuana and crack [...] [Partner] was arrested and died in prison [...] I have been arrested three times [sentence] I did two, four and eight months [...] (EPB - use of licit drugs at 14 and illicit drugs at 20 years of age).

The early involvement with drugs, the homeless situation and the shared use of drugs with the 
partner favored the exchange of sex for drugs, as well as the involvement with drug dealers and the transportation of drugs (mules), prostitution, prison and exclusion at all levels.

Social exclusion implicates a dynamics of deprivation due to the lack of access to basic social systems, such as family, housing, health, among others. The process imposed to the life of the individual establishes a relationship of risk with some type of drug, whose frontier to exclusion is delimited by the beginning of social problems. ${ }^{2,14,18}$

Regarding parity, the women had between one and ten children, with a mean of four. However, as for the number of children under their custody, eight women had the custody of only two children, as the other had been given to strangers and/or family members - grandparents and/or uncles and aunts. Two cases stood out, in which one woman had five children but had the custody of none, and another who had ten children and lost permanent custody of seven, due to the use of drugs.

A document from a non-governmental organization that assists pregnant women living in a vulnerable situation in Maringá-PR reveals that these women are under 30 years of age but already have four to five children, and that even though they have been pregnant, they have never experienced maternity. They have used all types of drugs and traded the experience of maternity for crack; speak naturally regarding chemical dependence and, touched, mention their search for strengths to treat dependence. ${ }^{19}$

The lack of a governmental protection or a health care model towards adolescents, whose parents work out of or who live in fragile families, to deal with adverse situations is also an indication for the maintenance of drug use. ${ }^{15}$ Most of the times, the family does not have structure to cope with the problem. The lack of access to health care services, in which users and families can receive treatment alternatives and social reinsertion, reveals these individuals' unawareness regarding the care network of the Unified Health System.

Although it is believed that the intervention of health services has poor influence on drug abuse, since it is related to multiple social factors, pregnant women who use drugs are less assisted by prenatal services and present higher incidence of complications during pregnancy. The lack of follow-up by a health team during pregnancy, including the right to qualified nursing care, inadequate nutrition, absence of family support and maintenance of the consumption during pregnancy lead to premature childbirth, low-weight babies and other neonatal complications. ${ }^{12,20}$

Excluded from society, these women adopt the attitude of selling their body to obtain resources to buy drugs; under the effect of the drug, they lose the power to negotiate the practice of safe sex, and generate undesired children, who will have reduced chances of a different life from that of their parents. ${ }^{10}$

\section{FINAL CONSIDERATIONS}

The present study revealed that pregnancy and maternity did not act as a turning point for the analyzed population, and that the triggering factors for drug abuse and the maintenance of the addictive behavior over the life of the participants were related, at a lower degree, with individual characteristics of the women and, more positively, with sociocultural and psychosocial aspects of their life in the family and in the community. Microsocial factors, involving family, school and group determinants, which are known to be related with the consumption of drugs, were pointed out by all women.

The main individual factors were the early age range at drug use initiation, allied to low education level and/or school evasion, and not entering the labor market. If considered as individual factors, the evolution of pre-adolescence/young adult age, personality traits, attitudes towards health and drug use, and personal motivations, were not present in the studied group.

It was verified that primary and emotional bonds of the women may be described as weak, due to the conflicting relationships and inadequate family dynamics, in which the attitude of the family and partners favored the addictive behavior. The weak family bond and the conflicts, represented by the presence of physical and psychological violence, and the love relationships with partners who used and dealt drugs were determinant for the use/maintenance of the consumption and social exclusion of these women. Longevity in the use of drugs determines a pattern of exclusivity with them.

The early involvement with drugs favored the practice of prostitution and the involvement with drug dealing and minor dealers to assure the easy access to the drugs, generating a cascade of directly related happenings. The arrest, resulting from these happenings took place in several mo- 
ments in the life of these women, and multiparity, with spontaneous or compulsory donation of their children, may be determinant for the pregnancy denial, whether it is due to the low self-esteem as a result of the events, to the poor association with the maternity experience or to a "culture" of greater commitment to the group of users.

Despite the limitations of this study, resulting from the difficulty of access to female drug users and, consequently, reducing the number of study subjects, the data obtained may be used as a strategy to plan preventive proposals towards drug abuse, taking into consideration the triggering factors for drug use, in a dependent population.

\section{REFERENCES}

1. Pratta EMM, Santos MA. Reflexões sobre as relações entre drogadição, adolescência e família: um estudo bibliográfico. Estud Psicol. 2006 Set-Dez; 11(3):315-22.

2. Raup LM, Adorno RCF. Jovens em situação de rua e usos de crack: um estudo etnográfico em duas cidades. Rev Bras Adolescência e Conflitualidade. 2011; (4):52-67.

3. Carlini EA, Nappo AS, Noto AR, Sanchez ZVDM, Moura YG, Carlini CMA, et al. Livreto informativo sobre drogas psicotrópicas. $7^{\mathrm{a}}$ ed. Brasília (DF): Centro Brasileiro de Informações sobre Drogas Psicotrópicas, Secretaria Nacional de Políticas sobre Drogas; 2011.

4. Zilberman ML, Hochgraf PB, Andrade AG. Gender differences in treatment-seeking brazilian drugdependent individuals. Subst Abus. 2003 Mar; 24(1):17-25.

5. Martins MC, Pillon SC. A relação entre a iniciação do uso de drogas e o primeiro ato infracional entre os adolescentes em conflito com a lei. Cad Saúde Pública. 2008 Mai 24(5):1112-20.

6. Roehrs H, Lenardt MH, Maftum MA. Práticas culturais familiares e o uso de drogas psicoativas pelos adolescentes: reflexão teórica. Esc Anna Nery. 2008 Jun; 12(2):353-7.

7. Brusamarello T, Maftum M, Mazza VA, Silva AG, Silva TL, Oliveira VC. Papel da família e da escola na prevenção do uso de drogas pelo adolescente estudante. Ciênc Cuid Saúde. 2010 Out-Dez; 9(4):766-73.

8. Wright MGM, Chisman AM. A saúde internacional, o fenômeno das drogas e a profissão de enfermagem na América Latina. Texto Contexto Enferm. 2004 Abr-Jun; 13(2):264-71.

9. Schenker M, Minayo MCS. Fatores de risco e de proteção para o uso de drogas na adolescência. Ciênc Saúde Coletiva. 2005 Jul-Set; 10(3):707-17.

10. Oliveira LG, Nappo SA. Caracterização da cultura de crack na cidade de São Paulo: padrão de uso controlado. Rev Saúde Pública. 2008 Jul; 42(4):66471.

11. Minayo MCS. Organizadora. Pesquisa social: teoria, método e criatividade. $24^{\mathrm{a}}$ ed. Petrópolis (RJ): Vozes; 2010 .

12. Yamaguchi ET, Cardoso MMSC, Torres MLA, Andrade AG. Drogas de abuso e gravidez. Rev Psiq Clín. 2008; 35(Supl.1):44-7.

13. Piko B. Perceived social support from parents and peers: which is the stronger predictor of adolescent substance use? Subst Use Misuse. 2000 Mar; 35(4):617-30.

14. Seleghim MR, Marangoni SR, Marcon SS, Oliveira MLF. Vínculo familiar de usuarios de crack atendidos em uma unidade de emergencia psiquiátrica. Rev Latino-am Enfermagem [online]. Set-Out 2011 [aceso 2012 Out 30];19(5):[9 telas]. Disponivel em: http:/ / www.scielo.br/pdf/rlae/v19n5/pt_14.pdf

15. Ballani TSL, Oliveira MLF. Uso de drogas de abuso e evento sentinela: construindo uma proposta para avaliação de políticas públicas. Texto Contexto Enferm. 2007 Jul-Set; 16(3):488-94.

16. Drezett J, Caballero M, Juliano Y, Prieto ET, Marques JA, Fernandes CE. Estudo de mecanismos e fatores relacionados com o abuso sexual em crianças e adolescentes do sexo feminino. J Pediatr. 2001 SetOut; 77(5):413-9.

17. Milani RG, Loureiro SRA. Famílias e violência doméstica: condições psicossociais pós ações do conselho tutelar. Psic: Ciênc Prof. 2008 Mar; 28(1):5067.

18. Epele M. Sujetar por la herida: una etnografía sobre drogas, pobreza y salud. Buenos Aires (AR): Paidós. 2010 .

19. Amaral T. Mulheres "trocam" a maternidade pelo crack. O Diário.com, Maringá, 17 Ago 2011 [acesso 2011 Nov 10]. Disponível em: http:/ / www.odiario. $\mathrm{com} / \mathrm{maringa} /$ noticia/468561/mulheres-trocam-amaternidade-pelo-crack/

20. Rodrigues DT, Nakano AMS. Violência doméstica e abuso de drogas na gestação. Rev Bras Enferm. 2007 Jan-Fev; 60(1):77-80. 